\author{
Биљана С. РИСТИЋ* \\ докторанд на Филолошком факултету \\ Универзитета у Београду
}

\title{
ГОВОРНИ ЧИНОВИ МОЛБИ И ЗАХТЕВА У ПИСМИМА КНЕЗА МИХАИЛА ОЦУ МИЛОШУ ОБРЕНОВИЋУ
}

\begin{abstract}
У раду се бавимо писмима које је кнез Михаило писао свом оцу Милошу Обреновићу у периоду од 1845. до 1858. године. Укупно је сачувано 229 страна текста, а налазе се у Универзитетској библиотеци у Београду. Нарочито нас је занимао начин на који кнез вербално подстиче оца да нешто за њега учини. Ексцерпирали смо примере који илуструју реализацију говорног чина молбе и захтева. У формулисању исказа аутор писама најчешће користи изразе: молим, молио бих, изволите, молим Вас изволите итд.
\end{abstract}

Кључне речи: писмо, кнез Михаило Обреновић, кнез Милош Обреновић, учтивост, говорни чинови, молба, захтев.

1. Михаило, син Милоша Обреновића, ${ }^{1}$ образовани кнез, у два наврата је владао Србијом средином деветнаестог века (1839-1842. и 1860-1868. године). Према нашим сазнањима, кнез је написао текст једног епитафа и три песме: „Што се боре мисли моје”, „Светски путник” и „Молитва кнеза српског Михаила на брегу морском”. Овим песмама бавили смо се у досадашњим истраживањима, те смо, трагајући, наишли и на преписку коју је кнез водио са својим оцем, тачније на писма која је он слао оцу. Сматрамо да је анализа тих писама следећи корак како бисмо заокружили целину. Ова писма нуде увид у језик ученог човека средине XIX века и остварење тог језика у једној специфичној, епистоларној, комуникацији.

Циљ рада је да, пошто немамо податке да је преписка до сада била предмет анализе, опишемо из чега се она састоји и каква је тематска структура

\footnotetext{
*biljana.ristic.247@gmail.com

${ }^{1}$ „Михаило Обреновић био је сасвим другачији човек него његов отац Милош. Милош је био неписмени сељак, а Михаило један лепо образовани западњак” (Јовановић 1963: 118). Са тим да су отац и син били две посве различите личности, слаже се и Симо Ћирковић, који каже да је Милошевв млађи син Михаило имао у себи само трачак очевог карактера и да је и сам осетио његову немилост и прекор (2011: 13).
} 
писама. Ако узмемо у обзир да су аутор писама и адресат - отац и син, да су били кнежеви Србије у једном периоду живота и да су писма настала у XIX веку, интересује нас како су време у којем је преписка настала и комуникациони образац епистоларног општења тог доба моделовали њихову комуникацију. Одређеније, занима нас како је кнез Михаило изражавао своје молбе и захтеве да (му) отац нешто учини и томе ћемо посветити главни део рада.

Корпус за анализу представљају поменута писма која је кнез упутио свом оцу. Немамо увида у писма која му је кнез Милош послао као одговор, нити податак да су та писма сачувана.

2. Укупно је сачувано 229 страна текста, при чему свако писмо у просеку има три стране. Датирана су и обухватају период од 1845. до 1858. године. То je, дакле, време између две владавине кнеза Михаила, када је Србијом владао кнез Александар Карађорђевић. Чувају се на Одељењу реткости у Универзитетској библиотеци Светозар Марковић у Београду, под сигнатуром 871.

У писмима син пише оцу о општим темама које се тичу догађаја и људи које заједнички познају, али и о својим личним проблемима, здрављу и слично. Писана су на чистом белом папиру, а оно што је занимљиво је да се на некима од њих налази суви жиг у виду грба Кнежевине Србије.

3. Тематска структура и изглед писама. Иницијална форма обраћања увек је иста: „Ваша Свђтлость / Милостиви Родителю”. Поред тога што указује на то коме се аутор обраћа, представља и начин да кнез искаже особито поштовање према оцу коме, као син, увек персира. Обраћање са „Ваша Свътлости/Ваша Светлост” није својствено само почетку писма, већ се јавља и на осталим местима, упоредо са формом „Ви”.

Тело писама обично почиње тако што се аутор позива на претходно писмо, које му је отац послао, и прецизира кад га је добио. Затим пише о темама које су тренутно актуелне. Набројаћемо неке:

- куповина коња;

- бирање послуге;

- селидбе кнеза Михаила по Бечу и проблеми са власницима станова;

- здравствени проблеми и аутора и оца;

- догађаји из живота људи које заједнички познају (Михаилова жена Јулија, Ана Рофелзберг, кнез Шварценберг, црногорски владика...);

- новац;

- временски услови;

- жеље поводом празника;

- планови везани за куповину некретнина;

- молбе оцу да нешто учини.

Иако о својим здравственим проблемима кнез неретко пише и на почетку тела писма, чест образац је да, пре финалног поздрава оцу и закључења писма, констатује како је здрав и да то исто и оцу жели.

Постоје варијације у финалном обраћању, али је оно редовно у знаку изражавања најдубљег поштовања, ,љубљења родитељске руке” и потписа аутора као „покорног сина М. М. Обреновића”. На пример: „Любећій вам 
отачаску руку, пребивам / ваше Светлости / покорни син / ММОбреновић” (4. августа 1848); „Любим вам руке и препоручуєм се у отачаску милост / ва. Светлости / покорни син / ММОбреновић (3/17. јула 1857)”.

4. Што се досадашњих истраживања и текстова релевантних за тему овог рада тиче, издвојили бисмо монографију Форме учтивости Бојане Милосављевић (2007). Ауторка се бавила формама учтивости које се употребљавају у типизираним ситуацијама. Посебно се осврнула на следеће говорне чинове: молба, извињење, захваљивање, честитање и саучешће. Њено истраживање је спроведено на грађи коју чини новосадски корпус разговорног језика и корпус који је ауторка сама формирала. Део који се тиче говорног чина молбе послужио нам је као важан путоказ у нашој интерпретацији.

Теоријским оквиром епистоларног дискурса, описом његових структурних нивоа и контрастирањем појединих обележја (између осталог и говорним чиновима молбе и захтева) бавила се Људмила Поповић (2010) у монографији Епистоларни дискурс украјинског и српског језика. Корпус за истраживање представљала је преписка, приватног и пословног типа, на српском и украјинском језику, затим објављена књижевна преписка украјинских и српских писаца, писма из дневне штампе, рекламе. Ауторка у делу о директивним доворним чиновима прво приказује исказивања молби и захтева за украјински језик, затим за српски, а онда их контрастира.

Остале студије које се тичу учтивости, говорних чинова, исказивања молби и захтева, биће поменуте у одговарајућим деловима рада. Оне су нам биле од значаја, пре свега, да бисмо наш покушај анализе теоријски одредили, али и код исцртавања оквира за посматрање и презентовање резултата.

5. Када се говори о учтивости, треба разликовати учтивост као друштвено понашање једне говорне заједнице од језичке учтивости ${ }^{2}$ која се, као термин, користи у описивању комуникативне интеракције. Српски језик нема у свом систему категорију учтивости, већ има језичка средства, форме, којима се учтивост исказује. То су, пре свега, форме говорне етикеције, као што су поздрављање, извињавање, захваљивање, честитање, молба итд. (Милосављевић 2007: 21).

Начин на који кнез комуницира са својим оцем, како му се обраћа, како од њега тражи да му нешто испуни и сл. карактеристичан је за време (и комуникацијске обрасце у писаном општењу, као обележју тог времена) у коме су писма настала и друштвени статус учесника комункације, али показује и личне одлике и стил аутора. Такође, и то што је адресат заправо говорников отац и некадашњи кнез Србије, делом моделује комуникацију у смеру исказивања најдубљег поштовања. ${ }^{3}$

\footnotetext{
${ }^{2}$ Језичка учтивост је скуп говорних стратегија којима се у говорном чину успоставља сараднички однос (онај однос међу саговорницима који обезбеђује успешну комуникацију) са саговорником, а које се могу реализовати устаљеним, конвенционалним језичким формама говорне етикеције, али и формама које нису конвенционалне, већ представљају говорников слободан избор (Милосављевић 2007: 26).

${ }^{3}$ Ако посматрамо медијум комуникације, овде је очигледно реч о писаној комуникацији, а према начину комуникације, рекли бисмо да је пре реч о формалној комуникацији са елементима неформалне, него о неформалној са елемнтима формалне.
} 
Иако се као важна особина разговорног језика наводи да саговорници „обично не воде много рачуна о форми свог исказа зато што немају времена да га брусе и дотерују, а и зато што су свесни да је упућен само једном човеку и ефемеран” (Кликовац 2008: 119), овде треба имати на уму да је реч о епистоларној комуникацији као нарочитом виду писане реализације разговорног језика, али стилски подигнутој захваљујући друштвеној позицији саговорника и свести о томе да ће преписка (вероватно) бити сачувана.

Молба ${ }^{4}$ се може дефинисати као учтиви захтев, или чак као учтиво наређење (Милосављевић 2007: 37) којим се адресат подстиче на неко делање. Говорник свој захтев или своју молбу може да изрази на различите начине. Што захтев треба да буде учтивији, питање је индиректиније (уп. Јанева 1984; Кликовац 2008: 121). Форме којима се исказује молба могу се поделити у две групе: Једну представљају форме оријентисане према говорном лицу (перформативни искази) и њима се исказује илокуција, тј. говорникова намера (молим, замолила бих Вас...). Другу групу представљају форме оријентисане према адресату и њима се исказује чин који адресат треба да изврши (размисли, можете ли...) (Милосављевић 2007: 76).

Језичка средства којима се императивност модификује 5 представљају маркере учтивости. За српски језик најтипичније је модификовање императивног израза уметањем перформатива ${ }^{6}$ молим те/Bac којим се на експлицитан начин прецизира комуникативна функција императивног израза (Милосављевић 2007: 51-52). У усменом говору илокуција ${ }^{7}$ перформатива молим mе/Вас може бити десемантизована (Поповић 2000: 237). У тим случајевима перформативи молим те/Вас представљају окамењене перформативе који су експоненти конвенционалног говорног чина којим се успоставља говорни контакт и исказује спремност на сарадњу и осигурава се одговарајућа реакција (Милосављевић 2007: 46). Већи степен учтивости у исказивању молбе постиже се формама којима се илокуција исказује индиректније од форми са експлицитним перформативом. То су најчешће имплицитни перформативни изрази (у потенцијалу и футуру) и упитне варијанте перформатиивних израза (Милосављевић 2007: 48).

Кнез Милош Обреновић, као адресат коме је анализирана преписка упућена, статусно је надређени саговорник у односу на свог сина кнеза Михаила, који му пише.

\footnotetext{
${ }^{4}$ Молбе, уз захтеве, наређења, препоруке и сл., припадају директивима, то јест говорним чиновима којима се саговорник подстиче или наводи да нешто учини (Поповић 200: 215).

${ }^{5}$ Меј (1994: 491-515) разликује унутрашње и спољашње модификовање израза. Прво се врши у оквиру самог императивног исказа, а друго изван њега.

${ }^{6}$ Главно својство перформатива није да експлицирају и прецизирају радњу која се њима врши, већ да они могу бити употребљени за вршење одређене радње (Серл 1991: 14-15).

${ }^{7}$ Остин (1994: 110-125) изрицање исказа посматра као извођење у три чина: локуционом, илокуционом и перлокуционом. Под илокуционим чином подразумева изрицање исказа које је истовремено и чињење. Такође, Серл (1981: 5) сматра да је илокуциона срж говорног чина заправо сврха чина, те да би она код директива била да се саговорник наведе да изврши нешто.
} 
6. Кнез Михаило за исказивање молбе користи различите форме. У даљем тексту наводимо примере ексцерпиране из грађе и класификоване према форми у којој је молба исказана.

\section{молим (Вас)}

* (3/15. феб. 1854) Молим вас да моє поклоненіє и поздрав Господину Генералу Коцебу и гос. Калчинском изявите.

* (4. јан 1857) Моя е намера била као што сам ва. Св. писао, да мало доцниє дођем к’ вама у Хайделберг, но сад ћу овде остати по жель вашой у писму изявльной, само молим вас да наложите Кочи нек ме пространіє извъети шта вели Г. Хеліус о вама и за колико времена он мисли да ће бити нуждно да код нъга останете.

* (5/17. феб. 1857) Ако вам и у будуће какав вла заиште новаца у заям, па вам рекне да се мора давити ако му не дате и обрицао буде што на сто интереса дати, молим вас баш му не дайте, него на послетку пошльите га к' мени, я ћу показати дунав, па нек скаче, ер то є крайньи безобразлук од Светлога вла.

* (18/30. март 1854) Међу тим, будући да он на сваки начин за тамо полази, я молим да га ва. Св. по обичаю свом милостиво примите и ако $є$ могуће у нъговом предузећу му помогнете, чему би се я одвећ радовао, опоминяюћи се свію оній обвезателни услуга коє ми є нъгов отац указао за време мога у Трієсту бавленя.

* (5/17. март 1854) Молим опет да поздравите Господу Коцебуа и Калчинског.

Експлицитни перформатив ${ }^{8}$ молим вас користи се као модификатор за ублажавање форми да изявите, да наложите, не дайте. Перформатив молим вас овде има улогу унутрашњег модификатора императивног исказа.

Изразом молим (Вас) кнез свој захтев учтиво формуше као молбу и исказује га директно (императивом или $\partial a+$ презент), али пристојно. Додатни вид ублажавања исказа је комбинација условне реченице са везником ако + перформатива молим вас. У трећем од наведених примера, реч је о ситуацији где услов за реализацију жељене радње не зависи од саговрникове (очеве) жеље или могућности, већ од спољашњих фактора. Притом, поменута реализација радње, чак и ако се оствари, не доноси добро директно говорнику, те стога овде није реч о уобичајеној молби где говорник тражи нешто за себе.

\footnotetext{
${ }^{8}$ Војводић (1997: 129-130) под експлицитним перформативним глаголима подразумева оне са граматичким обележјем 1. лица једнине или множине апсолутног презента само глагола несвршеног вида (молим нпр.) Сви остали глаголски облици чине имплищитне перформативе (замолио бих, хтео сам да замолим). Исти аутор (1997: 134) варирање између експлицитних и имплицитних перформатива доводи у везу са степеном учтивости.
} 
за (родитељску) милост молим

* (6/18 јул 1858) Я за милост молим и досаду вам чиним.

* (14/28. апр. 1856) Неколико пута сам се наканьивао да ва. Св. пишем и из нова - и сам не знам по кой пут - за родительску милост молим, коє се сад у Букрешу бивши, не смедог усудити да устмено учиним. А и тешко се $є$ усудити онога за милост молити, кой и не чекаюћи молбе из дана на дан милост свою просипа и излива.

* (6/18 јул 1858) Као што ће вам Доктор саобшчити, я за милост молим, ако молити смем, без вашег оштећеня, то єст да ви за себе приходе Брке, Нагоя и Мавродина задржите єр мени за мой обични живот не треба виђе од онога што ми Пояна и добра у Србій доносе.

Иако израз за милост молим не представља говорникову жељу да адресат изврши конкретну акцију, када се кнез овако обрати оцу, он му исказује нарочито поштовање и тиме комуникацију даље контектуализује тако што ствара атмосферу за исказивање конкретног захтева који ће тек уследити у наставку (умилостивљује и смекшава оца). Нарочити вид ублажавања степена наметања је и употреба условне реченице са везником ако која и сама садржи глагол молити: ако молити смем.

\section{молећи (вас)}

* (10. март 1857) Молећи вас да одма Цинеру горенаведени налог издате, препоручуєм се у отачаску милост и остаєм / ваше Светлости / покорни син / ММОбреновић

* (8. апр. 1857) Я вама ово доводим до знаня, молећи да учините расположень нужно да се Хилел намири.

Због употребе глаголског прилога садашњег (према горе приказаним примерима са презентским облицима) препознајемо да је степен наметања говорникове жеље овде мањи, те да је ова форма индиректнија.

\section{(ја) бих молио}

* (11/23 јули 1848) Чувшій да неку промену Ваша Свътлост учинити намерава са моима коньма из Русіе дошавшима, я би моліо да се никакво расположенъ с ньима не чини без моєг одобреня и уредбе.

Врло учтива молба, где се вербално ублажава утицај на адресата да изврши оно што говорник жели, постиже се тиме што обраћање у делу након я би моліо није директно (у другом лицу (да не чините)), већ гласи да се не чини. Да кнез Михаило ово чињење очекује баш од саговорника, а не од неког трећег лица, видимо из дела који претходи (чувщій да неку промену Ваша Свътлост учинити намерава са моима коньма из Русіе дошавшима), где је кнез Милош јасно експлициран као вршилац могуће будуће радње. Овим поступком говорник се додатно дистанцира од адресата. 
Већ смо у фусноти навели да варирање између експлицитних и имплицитних перформатива утиче на то како ће се исказ перципирати са становишта учтивости. Потенцијал ( $а$ бих молио) је индиректинија, те стога и учтивија форма од апсолутног презента (молим Вас).

\section{мислио сам молити}

* (29/17. нов. 1857) Предлажући ва. Св. ове и оваквимподобне просячине, био сам науміо да се и за мою душу мало постарам и попросим и то овако: Науміо сам на сваки начин у Граду квартир узети, [...] мисліо сам вас сад за то молити и дозволенъ искати да при земльи направим штале и шупу.

Индиректније исказивање илокуције, у односу на наведене примере са апсолутним перформативом молио бих, говорник постиже глаголом мисли$m u$, циљано употребљеним у перфекту које је позициониран испред инфинитива молити.

\section{имам молбу/молбу имам}

* (13/27. авг. 1856) Јоште єдну молбу имам: дай Те ми прилику, пошто време аренди наши добара изтекло буде, привредити и заєкономисативам како би се в. Св. одужіо...

* (8/20 јан. 1857) Имам єдну молбу, и та се у томе састой: да наложите Кочи нек ме извъсти како стой са плацевима кућним у Савамали у Београду, то єст гди є дворац и око нъга.

Имајући у виду блискост између себе и оца, исказом имам молбу/молбу имам кнез Михаило открива своју намеру и жели да отац делује у скаду са тим. Илокуциони чин је овде исказан у речи молба.

\section{молим да изволите}

* (1/13. апр. 1854) Молим да изволите мой поздрав изявити Господину Генералу Коцебу ако $є$ у Букрешу, као и Господину Халчинском и Фонтону.

* (4. авг. 1848) Найпре дакле молим да изволите овде приложеній 20 фор. среб. послатій ми примити, а по томе овде неколико изложеній речій, одговор на горепоменуто писмо, саслушати изволите: (садржај писма)

* (10. март 1857) Ако до тога дође, оно є врло хрђаво и мени се валя одма селити из Беча, зато молим да изволите ва. Св. наложити Цинеру нек ову горню суму одма исплати, док се іоште єкзекуція ніє почела, $\epsilon p$ ту помоћи друге нейма, платити се мора свакояко, па боль добровольно него да се ларма диже.

* (12. јул 1857) Међутим молим ва. Св. да ми изволите у писму назначити до коє суме могу попустити кад би се ко явио за одкупльиванъ вексли, да не би доцніє опет морао чекати на ваш одговор. 
* (16/28. март 1857) Ви ньга познаєте тако као и я и зато ніє нужно да са тиме бише пуним артию, него само молим да изволите ми ваше решеніє саобштити у томе призреню, како би га я извъстіо да нуждне кораке он са своє стране учинити може код Министра правосудія за коначни одпуст свой из службе.

* (6/18. окт. 1857) я ћу є сад опет тражити и рећи іой нек се спреми за пут докле іоште Пароплови по Дунаву иду, а међутим молим да ми изволите писати желите ли и сад да я пошльм, ако се узможе, и ни сте ли, може бити већ другу какву куварицу нашли и узели.

* (4. феб./23. јан 1857) Као што ва. Св. изявисте желю да сами ви одговор дате за плац под Пиваром, кой желе одузети у Србій правителство, то молим да у томе призреню налог издати изволите Г. Стояковићу.

Молим (...) да изволите... представља посебно занимљиву конструкцију којом говорник подстиче адресата да нешто учини. Наиме, први део је усмерен према говорнику, док је други део усмерен према саговорнику. Такође, видимо да у већини примера из ове групе поменутом изразу претходи подробније објашњење ситуације, што овакав вид изражавања молбе сврстава у нарочито језички учтиве.

\section{(ја) бих молио да изволите}

* (29/17. нов. 1857) Мени є наравно цела ствар са свим непозната, и зато я би моліо да изволите ва. Св. о томе налог издати Стояковићу, кой ако до сад ніє тамо дошао, мораће скорим доћи.

Слично претходном случају, где се употребом потенцијала бих молио обраћање чини мање директним, овде видимо пример када се већ ублажено обраћање додатно ублажава изразом да изволите који је усмерен према саговорнику. Такође, употреба потенцијала (бих молио да изволите) исказ чини индиректнијим и учтивијим у односу на употребу презента (молим да изволите).

\section{изволите}

* (14/26. апр. 1852) Да би првобитно ваше добро и редко здравль опет задобили, изволите се ваша Св. решити и овамо доћи, па после како вам се свиди, тако и учинитИ: или овде остати или у Париз ондашньим докторима отићи.

* (6/18. јан. 1854) Сад ако ва. Св. имате милост што подарити му, не сматраюћи на ову ньгову суму, то изволите ми налог дати.

* (12. март 1852) И ако се ва. Св. на то согласите изволите ми писати кога од доктора да тражим...

* (12. јун / 31. мај. 1857) Но ако ва. Св. на сваки начин желите да тамо дођем, изволите ми писати да се одма на пут и кренем.

* (12. март 1852) Изволите ми дакле налог дати у томе призреню. 
* (14/26. апр. 1852) Само изволите ми напред писати да вам собе препоручим, єр ни єдне собе се не може наћи.

* (7. феб. 1857) Изволите в. С. расположити како за найболь будете нашли.

* (16/28. феб. 1851) Изволите и в. С. Миловану наложити да и он мебле и остале ствари спреми и пакує и у влашку ишль или носи, па ако она хтене ићи оно нека є између четири дувара.

Наведени примери приказују две врсте радњи посматраних према томе коме користе. У првом примеру видимо да кнез моли оца да дође зарад сопственог добра. Чак и у том случају он осећа потребу да своју молбу тако учтиво формулише и да своје обраћање учини мање директним и учтивијим.

Употреба условне реченице са везником ако омогућава кнезу као говорнику да могућност извршења захтеване радње препусти адресату (оцу).

Четири последња примера у овом делу (када изразу изволите не претходи условна реченица) представљају директнију форму искивања захтева од претходне, но и даље учтиву.

\section{добро би било/најбоље би било}

* (6. апр. 1852) Добро би било кад би ми ваша Свет. явили гди желите бити у квартиру да се за валяне собе из напред постарам...

* (11/23. апр. 1857) Добро би било кад би ва. Св. писали у Београд Стояковићу и препоручили му да іой сироти на руци буде єр е мени Куниберт пре неколико месеци писао да му є у томе ва. Св. подпора необходима.

* (13/25. апр. 1857) Я мислим да би найболь било кад би ва. Св. Јови у Париз писали, да се он са ньиме споразуме како є тамо на месту, єр и Кунибертов брат є у Паризу стран.

У овим примерима говорник изрицање онога што жели да саговорник учини, модификује тако да га представља као сугестију (добро/најбоље би било). Такође, молбу додатно ублажава условном реченицом (кад би...).

Кнез Михаило Обреновић у свим писмима, као израз нарочитог поштовања, као што смо већ поменули, персира оцу или му се обраћа са Ваша Светлост(u). Некада је ова форма експилирана, а некад се подразумева на основу садржаја остатка реченице, што видимо у наведеним примерима. Нисмо примере посебно разврставали према томе да ли је обраћање експлицирано и којом формом или не, како не бисмо компликовали анализу. Но то не значи да не узимамо у обзир поменуто као начин исказивања учтивости (али и поштовања комуникацијских обичаја).

7. На основу анализе можемо извести следећи закључак. У раду смо се бавили начинима на које кнез Михаило Обреновић исказује молбу или захтев свом оцу Кнезу Милошу Обреновићу. Иако је реч о епистоларној комуникацији оца и сина, у њиховој комуникацији уочава се статусна дистанца. Го- 
ворник је, наиме, по статусу подређен саговорнику. Комуникација је у знаку исказивања најдубљег поштовања. Син персира оцу.

Примере који показују реализацију говорног чина захтева или молбе смо ексцерпирали и класификовали према начину на који се чин реализује, то јест које речи и у којој форми се употребљавају: молим вас, молим да изволите, ја бих молио, ја бих молио да изволите, изволите, мислио сам молити, имам молбу...

Поред експлицитног перформатива молим, уочили смо случајеве са имплицитним перформативом молио бих. Употреба потенцијала молбу ублажава. Оба ова случаја представљају форму усмерену према говорнику и показују већи је степен индиректног исказивања илокуције (молба је учтивија), од примера са изразом изволите (форма усмерена према саговорнику), где је степен индиректности доста мањи, а молба директнија. Постоји и читав скуп случајева који су комбинација ова два: молим да изволите/молио бих да изволите. Уочили смо и мањи број примера кад је исказ формулисан као имам молбу..., мислио сам молити... итд. Слично претходном објашњењу, и овде је молба исказана учтиво, индиректно.

\section{ИЗВОРИ}

Кореспонденција Михаила и Милоша Обреновића, Сигн. 871. Одељење реткости Универзитетске библиотеке у Београду.

\section{ЛИТЕРАТУРА}

Војводић 1997: Дојчил Војводић, „Перформативни искази као резултат лексичких и граматичких значења глагола", Научни састанак слависта у Вукове дане, 26/2, Београд, 129-140.

Јанева 1984: Марија Јанева, „Учтиви барања во англискиот и македонскиот јазик”, Сојуз на друштвата за применета лингвистика на Југославија, Друштво за применета лингвистика на Македонија, Скопје, 155-160.

Јовановић 1963: Слободан Јовановић, Портрети из историје књижевнос$m и$, Нови сад: Матица српска.

Кликовац 2008: Душка Кликовац, „Из проблематике функционалних стилова", у: Језик и моћ, Београд, Библиотека XX век, 111-134.

Mej 1994: Song Mei Lee Wong, „Imperatives in requsts. Direct or impolite observations from Chenese", y: Pragmatics (4), 491-515.

Милосављевић 2007: Бојана Милосављевић, Форме учтивости у српском језику, Београд: Учитељски факултет Универзитета у Београду.

Остин 1994: Džon Ostin, Kako delovati rečima, Novi Sad: Matica Srpska.

Поповић 2010: Људмила Поповић, Епистоларни дискурс украјинског и српског језика, Београд: Филолошки факултет. 
Серл 1981: Džon Serl, Intentionality and Method. y: Journal of Philosophy, 78, $720-732$

Серл 1991: Džon Serl, Govorni činovi, Beograd: Nolit.

Ћирковић 2011: Симо Ћирковић, Кьаз Михаило Обреновић. Живот и политика. Београд: Дерета.

\author{
Biljana S. Ristić
}

\title{
PATTERNS OF POLITENESS IN THE LETTERS OF PRINCE MIHAILO TO HIS FATHER MILOS OBRENOVIC
}

\section{Summary}

The subject of our analysis is correspondence between Prince Mihailo and his father Milos Obrenovic with a special review on patterns of politeness and sons expression of respect for his father.

The letters are held in the Rare Books Department in the University Library Svetozar Markovic in Belgrade. It has a total of 229 pages of written text, and every letter has an average of three pages. The letters are from the period between 1845. and 1858. That is time between two reigns of Prince Mihailo, when Prince Aleksandar Karadjordjevic ruled Serbia.

The way Prince has correspondence with his parent in the 19th century sets apart from nowadays common way of correspondence of son with a father. The author uses formal form, he represents himself as humble and „submissive”, and gives his father a higher status. We are especially interested in the way which Prince expresses his demand/appeal for his father to do something for him. 